\title{
The Teaching Research on "Water Analysis Chemistry" Combined with Production and Education
}

\author{
Dong $\mathrm{Ru}$ \\ Shaanxi Key Laboratory of Ecological Restoration in Northern Shaanxi Mining Area, \\ Yulin University, \\ Yulin, Shaanxi 719000, China
}

\begin{abstract}
Yu Lin College as local colleges, for the training of applied talents, water supply, drainage science and engineering analysis of water chemistry teaching, it is an urgent need for them to carry out the teaching reform and innovation. Based on the analysis of water chemistry curriculum as an example, through the combination of production and education, school enterprise cooperation, cooperation and other forms of education, through the education integration, school - enterprise cooperation, cooperation and other cooperative education forms, to innovate the practice teaching system, focusing on the reform and innovation of innovative, comprehensive and design experiment, this method can explores the integration and reconstruction of teaching content system, and it can gradually completes the transformation of curriculum content and discusses the transformation of teaching content from " knowledge input - oriented" to " ability output - oriented ", from" knowledge system " to" ability system " transformation, and it also can realizes the overall promotion of talent cultivation quality.
\end{abstract}

Keywords-Integration of production and education; School enterprise cooperation; Teaching content system; Quality of talent cultivation

\section{THE IMPORTANCE OF TEACHING CONTENT REFORM OF WATER ANALYTICAL CHEMISTRY}

Water analytical chemistry is the basic course for students of science and engineering major in water supply and drainage, Water analytical chemistry, as the basis for important courses such as water quality engineering, aims to develop and train students' basic knowledge and expertise in water analytical chemistry, in particular, it is important to cultivate students' experimental operation and instrument operation ability, it is also important to cultivate students' rigorous analytical attitude, the ability to analyze problems independently and solve practical problems, with the development of water analytical chemistry and related disciplines, new contents and technologies of water quality analysis are emerging. At the same time, water analytical chemistry undertakes the role of "eyes" and "sentry" in the increasingly serious pollution control and monitoring of water environment [1], the demand of the market is increasing. But the talents who are we cultivate cannot meet the needs of social development. The main reason is that the traditional teaching method of water analysis chemistry curriculum is far from the requirements of training applied talents.

\section{ANALYSIS OF TEACHING SITUATION OF WATER ANALYSIS CHEMISTRY COURSE}

\section{A. Water analysis chemistry curriculum attaches importance to theory, light experiment, light practice}

There are 48 theoretical hours and 12 experimental classes in the course of Water Analytical Chemistry, the traditional teaching methods focus on classroom teaching and the teaching content is out of practice, although there are experiments, but basically relying on teacher's step, the experimental project is not connected with the actual work process, the basic experiment of the experiment mainly focuses on the basic operation of titration, such as the determination of alkalinity and hardness of water, which lack of instrument operation, innovative, comprehensive and design trisexual experiment. Moreover, the practice of water analysis chemistry has not yet been arranged, which can not meet the requirements of independent analysis and practical problem solving.

\section{B. Learning, light training in the process of teaching.}

Analytical chemistry is difficult, the principle and the instrument structure are complex, abstract and difficult to understand, students are difficult to master many concepts, many abstract, complex calculation, and many formulas, in the process of teaching, and we pay attention to theoretical teaching, knowledge input, students' passive acceptance, less interaction between teachers and students. Students take the initiative to practice very little, the students to find problems and raise questions less, students learning passive, low efficiency, the teacher's leading role is still more serious with the students' main role, the students do not have the specialized skills of water analytical chemistry, and the problem of poor operation and application ability is still not solved.

\section{The teaching materials used are not applicable to applied undergraduate university}

The textbook selects the " twelfth five - year plan" teaching materials for civil engineering majors in colleges and universities, with the same teaching materials used in the $985 /$ 211 university, this teaching material have many contents, chapters, and it also pay attention to the theory and the derivation, which emphasize the scientific research, with knowledge input as the main, it is the heavy theoretical 
research teaching material for the research university, which not suitable for the local colleges and universities applied talent training teaching material.

\section{The classroom teaching process is lack of case introduction, the separation of production and teaching}

In classroom teaching, they based on the existing teaching materials, according to the section to explain knowledge points and to teach with knowledge input - based, they rarely introduce case teaching and do not teach integration, students' learning can not interest, "knowledge" hanot turned into "ability ", especially the ability to apply and solve practical problems.

\section{COMBINING TEACHING WITH PRODUCTION AND TEACHING TO CARRY OUT TEACHING REFORM}

Through the analysis of the status quo, we can see that the teaching method and teaching mode of "water analysis chemistry" in our hospital are relatively old. in order to cultivate application-oriented talents, teaching reform should pay attention to experiment, practice and teaching integration, combined with our school reality, through field investigation, interviews, and our school joined the Yu Lin city as a platform, the transformation development pilot colleges of the Ministry of education as an opportunity to build a school - enterprise integration education mode mainly from the following aspects of reform.

\section{A. Establishing cooperative education mechanism with enterprise}

Relying on Yulin university and Yulin city enterprise industry - university - research alliance as an opportunity, to visit $1-2$ water treatment enterprises or chemical enterprise water quality analysis center for research and investigation, it can summarizes the capacity factors of water analysts in the demand of enterprises, and concludes the school-enterprise cooperation to educate people, leading the students to the second grade enterprise water analysis center to visit trainee center, assign analysis practice in the enterprise of water $\mathrm{Xi}$ exercise the third grade students to improve students' hands-on ability, analysis and problem solving ability.

\section{B. The introduction of classroom teaching case, to stimulate learning motivation}

In order to promote learning, teachers and students can effectively use information technology and modern education media and digital resources to teach and learn bilateral interactive activities in the information environment, the problems encountered in the students' participation in the internship process, such as the case form throughout the classroom teaching, at the same time we can invite enterprises to enter the classroom to teach students, so that students can learn from the use and from the motivation of learning, therefore students can find problems, put forward problems, solve problems, and finally achieve the purpose of innovation

\section{Setting up comprehensive, innovative and design experiments,}

Based on the inspiration of students' participation in the process of university-enterprise cooperation, refill the experiment teaching, and re-establish comprehensive, innovative and design experiments. We should mainly focus on the solution of the enterprise in the process of the comprehensive problems encountered in the enterprise, emergencies and other water quality problems [3], at the same time we also should increase the analytical operation of the three experiments, let the students contact with some precision instruments, such as learning spectrophotometer, mobile injection and other instrumental use and operation analysis to improve students' comprehensive ability

\section{Reorganizing the teaching content system}

According to the capacity elements of water analysts, integration and reconstruction, and re - organize the teaching content system, Starting with the transformation of the contents of the curriculum, the paper discusses the transformation from " knowledge input - oriented" to " ability output - oriented ", from" knowledge system " to" capability system, classroom learning is introduced into the case at the same time, which strive for the formation of modular curriculum system and fully embody the "integration of theory and practice of" teaching, it pay attention to the comprehensive application of knowledge, outstanding teaching content and the combination of production and education, improve the students' application ability.

\section{SUMMARY}

$\mathrm{Yu}$ Lin university, as a local undergraduate college, which aims at training applied talents and take water analytical chemistry course as an example, this article explores the reform and innovation of creative experiment, such as innovation, comprehensiveness, and design of three experiments, through the combination of production and education, school - enterprise cooperation, and other forms of cooperation. this article explores the integration and reconstruction of the teaching content system of water analysis chemistry, which reorganizes the teaching content system, and realizes the transformation from "knowledge input orientation" to "ability output orientation", from "knowledge system" to "ability system", breaking the old framework designed according to chapter content, it has completed the combination of knowledge logic and ability unit, and construct new teaching content. The school Strive to improve students' ability to analyze and solve problems. To improve the quality of personnel training in a comprehensive way.

\section{REFERENCES}

[1] Wang Huang Jun li. water analytical chemistry [M]. Beijing: China construction industry press, 2008: 23.

[2] Li Guo hui. discussion on the reform of water analytical chemistry experiment [J]. Journal of Hunan urban construction institute, 2002, 11 (2): $64-65$.

[3] Chen $\mathrm{Fu}$ rong, Chen qun, Xi Hai tao, et. construction of chemical engineering laboratory center under the concept of engineering education $[\mathrm{J}]$. Journal of Jiangsu institute of industry (social science edition ), 2008 (3): 112. 